\title{
Alcohol Consumption, Progression of Disease and Other Comorbidities, and Responses to Antiretroviral Medication in People Living with HIV
}

\author{
Manuela G. Neuman, ${ }^{1,2,3}$ Michelle Schneider, ${ }^{4}$ Radu M. Nanau, ${ }^{1,2}$ and Charles Parry ${ }^{4,5}$ \\ ${ }^{1}$ Departments of Pharmacology \& Toxicology and Global Health, University of Toronto, Toronto, ON, Canada M5S 1A1 \\ ${ }^{2}$ In Vitro Drug Safety and Biotechnology, MaRS Discovery District, 101 College Street, Suite 300, Lab 351, \\ Toronto, ON, Canada M5G $1 L 7$ \\ ${ }^{3}$ Institute of Drug Research, Canada \\ ${ }^{4}$ Alcohol and Drug Abuse Research Unit, South African Medical Research Council, Cape Town-Tygerberg 7505, South Africa \\ ${ }^{5}$ Department of Psychiatry, Stellenbosch University, Cape Town-Tygerberg 7505, South Africa
}

Correspondence should be addressed to Manuela G. Neuman, m_neuman@rogers.com

Received 6 September 2011; Revised 13 December 2011; Accepted 2 January 2012

Academic Editor: Frederick L. Altice

Copyright (C) 2012 Manuela G. Neuman et al. This is an open access article distributed under the Creative Commons Attribution License, which permits unrestricted use, distribution, and reproduction in any medium, provided the original work is properly cited.

\begin{abstract}
The present paper describes the possible connection between alcohol consumption and adherence to medicine used to treat human deficiency viral (HIV) infection. Highly active antiretroviral therapy (HAART) has a positive influence on longevity in patients with HIV, substantially reducing morbidity and mortality, including resource-poor settings such as South Africa. However, in a systematic comparison of HAART outcomes between low-income and high-income countries in the treatment of HIV-patients, mortality was higher in resource-poor settings. Specifically, in South Africa, patients often suffer from concomitant tuberculosis and other infections that may contribute to these results. Alcohol influences the use of medicine for opportunistic infections (e.g., pneumonia, tuberculosis), or coinfections HIV-hepatitis viruses-B (HBV) and C (HCV), cytomegalovirus, or herpes simplex virus. Furthermore, alcohol use may negatively impact on medication adherence contributing to HIV progression. The materials used provide a data-supported approach. They are based on analysis of published (2006-2011) world literature and the experience of the authors in the specified topic. Intended for use by health care professionals, these recommendations suggest approaches to the therapeutic and preventive aspects of care. Our intention was to fully characterize the quality of evidence supporting recommendations, which are reflecting benefit versus risk, and assessing strength or certainty.
\end{abstract}

\section{Introduction}

Failure to recognize alcohol behaviour remains a significant problem that impairs efforts directed towards the prevention and management of patients with alcoholic liver damage. Although there are limitations in the available data, the World Health Organization's Global Alcohol database, which has been in existence since 1996, has been used to estimate worldwide patterns of alcohol consumption, and it allows comparisons of alcohol-related morbidity and mortality. The burden of alcohol-related disease is highest in the developing world, including South Africa. Pithey and Parry [1] describe the association between alcohol use and human immunodeficiency virus (HIV) infection in a systematic review of sub-Saharan African studies. The authors present studies that have quantified the association between alcohol consumption and HIV infection in this region. They analyzed work performed between 2000 and 2008 that reported relative measures of the association between alcohol use and HIV prevalence and/or seroconversion rates. However, the authors sustain that in order to confirm causality, the use of clearly defined standardised measures of alcohol use is needed [1]. Patterns of alcohol consumption are expressed and regulated differently in diverse geographical regions. There are contradictory 
drinking guidelines defining low-risk and high-risk drinking in different countries. In the United States of America, the National Institute of Alcohol and Alcohol Abuse (NIAAA) and the United States Department of Agriculture define low risk drinking as $\leq 14$ drinks/week and $\leq 4$ drinks on any day for men. For women, the definition of low risk drinking is $\leq 7$ drinks/week or $\leq 3$ drinks on any day (http://www.rethinkingdrinking.niaaa.nih.gov/; http://www.cnpp.usda.gov/dgas2010-dgacreport.htm). Proposed guidelines specific for each nation make it difficult to conduct an international generalization of "moderate, lowrisk drinking" versus "high-risk drinking."

\section{Material and Methods}

We performed a systematic review of published PubMed literature, searching for articles that contained information about "alcohol", "HIV" and "antiretroviral therapy" published between January 2006 and June 2011. We did not limit our search to literature published in English. We found over 365 results using the key words "alcohol," "adherence," "ART" and "HIV", from which we selected 230 articles that we analyzed.

From these initial results, we selected 25 articles to be included in the "disease progression" sections and 38 articles to be included in the "adherence" section. Particular attention was placed on those papers that provided an indication of the type and the amount of alcohol consumed. In order to obtain more focused results so that we could, where necessary, refer to South Africa, we also included the words "South Africa" in the search. However, we did not have "South Africa" as an exclusion criterion. Main reasons for excluding articles include poor characterization of alcohol consumption patterns, incomplete or poor characterization of adherence to medication or/and disease progression, in vitro or in vivo animal studies, and studies where the focus was on comorbid diseases and addictions, as well as treatments for these conditions, whose effects could have undermined that of alcohol (e.g., environmental habits (drugs of abuse, smoking), viral infections (cytomegalovirus, herpes simplex virus, hepatitis $\mathrm{C}$, hepatitis B), malaria, tuberculosis).

Although not specific for the main topics discussed, some relevant papers published prior to 2006 contained important information that was used to reinforce our arguments and were therefore discussed as well.

Figure 1 illustrates the methods used for the literature search and the number of articles chosen for different subjects. Data accessible in this paper are descriptive in nature. All prevalence estimates of alcohol use are the data presented by their respective authors.

\section{Results and Discussion}

3.1. HIV and Alcohol Misuse. Rehm and Parry [2] described the link between alcohol consumption and infectious diseases in South Africa. Alcohol abuse is often associated with numerous facets of HIV disease progression, ranging from hepatotoxicity to immune system impairment. Table 1

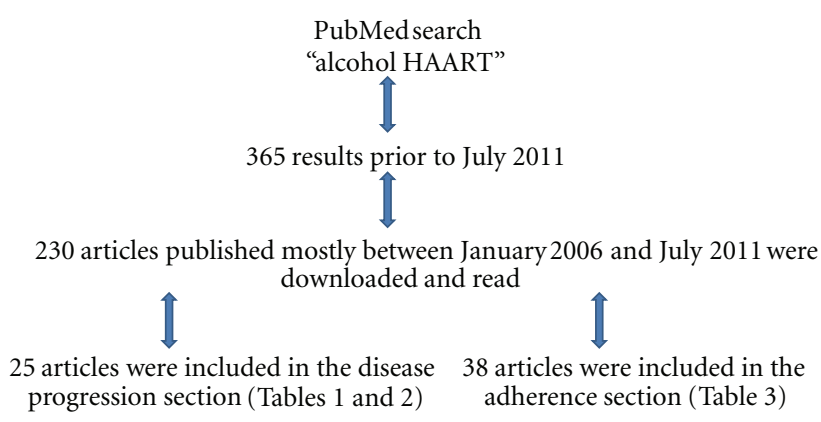

FIgURE 1: Methods used for literature search.

presents the role played by alcohol on the progression of HIV-associated disease symptoms.

Neuman et al. [3], Núñez [4], and Barve et al. [5] extensively reviewed hepatotoxicity associated with alcohol use and highly active antiretroviral therapy (HAART) administration. The development of lung infection was reviewed by Rehm et al. [6] and Quintero and Guidot [7], while the progress of cardiovascular diseases was reviewed by Freiberg and Kraemer [8]. Rosenbloom et al. [9] reviewed detrimental effects on the structure, chemistry, and function of the central nervous system.

Neuman et al. [3] discuss the interactions between therapeutic drugs used to minimize and control drug and alcohol dependence. Furthermore, drug-drug interactions occur between HAART and alcohol, different HAART components and methadone, or each one of the therapies with the other, thus contributing to a higher toxicity level. With the evolution of effective antiretroviral therapy (ART), survival of persons living with HIV and acquired immunodeficiency syndrome (AIDS) has increased dramatically, leading to more interactions with other liver related comorbidities such as alcohol and viral hepatitis and the drugs used to treat these diseases.

The following section will review several studies that analyzed the relationship between alcohol misuse and HIV disease progression. Two important laboratory determinants of the rate of disease progression are the $\mathrm{CD} 4^{+}$cell counts and the plasma viral load.

3.1.1. Role of Hepatitis Viruses on HIV. Hazardous drinking is often associated with liver disease $[10,11]$, particularly among hepatitis $\mathrm{C}$ virus (HCV) monoinfected patients and HIV/HCV coinfected patients [12]. Several interesting trends were observed in the MORTAVIC study, a multicentre prospective cross-sectional survey of French hospital departments of internal medicine and infectious diseases participating in the treatment of HIV-infected individuals $[13,14]$. From 215 deaths that occurred in 2003 among 20940 HIV positive, 27 (12.6\%) can be attributed to endstage liver disease. Of these, HCV coinfection was present in $25(92.6 \%)$ patients, alcohol consumption of any kind in $25(92.6 \%)$ patients, moderate alcohol consumption (30-60 g/day) in $12(44.4 \%)$ patients, and heavy alcohol consumption ( $>60 \mathrm{~g} /$ day $)$ in $7(26.0 \%)$ patients [13]. Over the previous decade, the proportion of patients dying from 
TABLe 1: Interactions between Alcohol and HIV Disease Progression.

\begin{tabular}{lll}
\hline Ref. $\begin{array}{l}\text { Study } \\
\text { settings }\end{array}$ & Population characteristics & Alcohol use patterns \\
\hline & Found an Association \\
\hline & & $\begin{array}{l}10.4 \% \text { reported hazardous drinking }(>14 \\
\text { drinks/week or }>4 \text { drinks/occasion for } \\
\text { men and }>7 \text { drinks } / \text { week or }>3 \\
\text { drinks/occasion for women })\end{array}$ \\
\hline 11$]$ USA & 696 HIV positive patients & \\
\hline
\end{tabular}

190 patients (71 HIV monoinfected,

[12] Italy $53 \mathrm{HCV}$ monoinfected and 66 $\mathrm{HIV} / \mathrm{HCV}$ coinfected)
Main findings
Hazardous drinking associated with liver disease, defined as aspartate aminotransferase to platelet ratio index $>1.5$ (RR 3.72, 95\% CI 1.40-9.87)

The extent of advanced liver fibrosis, defined as liver stiffness $\geq 9.5 \mathrm{kPa}$, correlate with alcohol intake (nonsignificant in HIV monoinfected patients, $P<0.001$ in $\mathrm{HCV}$ monoinfected patients and $P<0.04$ in HIV/HCV coinfected patients), but not with HAART exposure or duration of HAART

Alcohol consumption of any kind in 25 $(92.6 \%)$ of 27 patients who died from end-stage liver disease

Proportion of excessive alcohol consumption higher in 2003 compared to $1995(P<0.05)$

The combination of alcohol and HCV coinfection led 12 (25.0\%) deaths

Excessive alcohol consumption ( $>30 \mathrm{~g} /$ day) reported in $23(47.9 \%)$ of 48 patients who died from end-stage lived disease associated with death due to end-stage liver disease $(P=0.005)$

210 HIV positive patients with a history of injectable drug use or HCV (60 HIV positive and 150

[15] France HIV-negative). There were 41 (19.5\%) cases of liver individuals cirrhosis

2168 HIV positive patients,

[16] Spain including $181(8.3 \%)$ cases of cirrhosis
95 (52.5\%) cirrhotic patients admitted current or past alcohol abuse
76 patients suffered from excessive drinking, with similar rate between HIV positive individuals and HIV-negative
HIV positivity (OR 2.2, CI 1.1-4.5) and excessive drinking (OR 1.9, CI 1.0-3.9) independently associated with cirrhosis

91 HIV positive patients $30(33.0 \%)$ patients suffered from liver toxicity

[17] Spain $\quad \begin{aligned} & 10(11.0 \%) \text { patients suffered from } \\ & \text { severe liver toxicity } \\ & 43(47.2 \%) \text { patients coinfected with }\end{aligned}$

$\begin{array}{ll}\text { [17] Spain } & 10(11.0 \%) \text { patients suffered from } \\ \text { severe liver toxicity } \\ 43(47.2 \%) \text { patients coinfected with }\end{array}$

$\begin{array}{ll}\text { [17] Spain } & 10(11.0 \%) \text { patients suffered from } \\ \text { severe liver toxicity } \\ 43(47.2 \%) \text { patients coinfected with }\end{array}$ HCV and/or HBV

[20] USA $164 \mathrm{HIV}$ positive patients Patients consumed alcohol 88 (53.6\%) were hazardous drinkers

$300 \mathrm{HIV}$ positive patients,

[21] USA $82(27.3 \%)$ patients experienced pneumonia

$60 \%$ of sample reported prior or current alcohol abuse
Alcohol consumption associated with cirrhosis (OR 3.5, 95\% CI 2.5-4.8, $P<0.01)$
High alcohol consumption risk factor for liver toxicity (OR 3.35, 95\% CI 2.43-4.62, $P=0.01)$
Hazardous drinking associated with worsening of dyslipidemia (OR 3.18, 95\% CI $0.99-12.05, P=0.04$ )

Alcohol use independent predictor for pneumonia in HIV positive smokers $(P=0.004)$

Alcohol abuse independent predictor for bacteremic pneumococcal disease (OR 5.28)

Cerebrovascular ischemia associated with history of high alcohol intake (OR 7.13, 95\% CI 1.69-30.11, $P=0.007$ )

Synergistic interaction between alcohol abuse and HIV infection with respect to motor and visuomotor speed 
TABle 1: Continued.

\begin{tabular}{|c|c|c|c|c|}
\hline Ref. & $\begin{array}{l}\text { Study } \\
\text { settings }\end{array}$ & Population characteristics & Alcohol use patterns & Main findings \\
\hline$[26]$ & USA & $\begin{array}{l}31 \text { male HIV positive patients, } 27 \\
\text { patients with alcoholism, } 43 \\
\text { patients with HIV infection and } \\
\text { alcoholism comorbidity, and } 22 \\
\text { normal healthy controls }\end{array}$ & $70(56.9 \%)$ patients with alcoholism & $\begin{array}{l}\text { HIV and alcoholism comorbidity impair } \\
\text { upper motor limb to a greater degree that } \\
\text { HIV alone }(P=0.068) \text { or alcoholism alone } \\
(P=0.062)\end{array}$ \\
\hline$[27]$ & USA & $\begin{array}{l}40 \mathrm{HIV} \text { positive patients, } 38 \\
\text { alcoholic patients, } 47 \text { alcoholic HIV } \\
\text { positive patients, and } 39 \text { controls }\end{array}$ & $85(51.8 \%)$ patients with alcoholism & $\begin{array}{l}\text { Immediate episodic memory impaired in } \\
\text { HIV positive patients with alcoholism } \\
\text { comorbidity }\end{array}$ \\
\hline \multicolumn{5}{|c|}{ Did Not Find an Association } \\
\hline$[24]$ & USA & $\begin{array}{l}1539 \text { HIV positive patients } \\
881(57.2 \%) \text { reported } \\
\text { HIV-associated sensory neuropathy, } \\
\text { of which } 335(38.0 \%) \text { reported } \\
\text { neuropathic pain }\end{array}$ & $\begin{array}{l}845(54.9 \%) \text { had a history of alcohol } \\
\text { abuse or dependence }\end{array}$ & $\begin{array}{l}\text { History of alcohol abuse or dependence } \\
\text { not associated with neuropathic pain } \\
\text { caused by HIV-associated sensory } \\
\text { neuropathy }\end{array}$ \\
\hline$[28]$ & Italy & $\begin{array}{l}76 \text { HIV positive patients with } \\
\text { bacterial community-acquired } \\
\text { pneumonia } 32(42.1 \%) \text { were } \\
\text { receiving ART }\end{array}$ & $25(32.9 \%)$ alcohol abusers & $\begin{array}{l}\text { Alcohol abuse not associated with a longer } \\
\text { time before clinical stability was achieved }\end{array}$ \\
\hline$[29]$ & USA & $\begin{array}{l}299 \text { HIV positive patients. } \\
\text { Abnormal liver test results observed } \\
\text { in } 80(26.8 \%) \text { patients }\end{array}$ & & $\begin{array}{l}\text { Amount of alcohol consumed per week or } \\
\text { alcohol overuse not predictors of liver test } \\
\text { abnormalities }\end{array}$ \\
\hline$[30]$ & France & $\begin{array}{l}1175 \text { HIV-infected patients } \\
1048(89.2 \%) \text { were HCV coinfected }\end{array}$ & & $\begin{array}{l}\text { Alcohol consumption not associated with } \\
\text { HCV-related serious adverse reactions }\end{array}$ \\
\hline
\end{tabular}

AIDS decreased and the number of patients dying from endstage liver disease remained relatively constant. In recent times, the proportion of patients dying from end-stage liver disease is significantly higher (21 out of 1426 deaths $(1.5 \%)$ in 1995 versus 27 out of 215 (12.6\%) deaths in 2003, $P<0.01)$. Among patients dying from end-stage liver disease, the proportion of patients with HCV coinfection alone and the proportion of excessive alcohol consumption were significantly higher in 2003 compared to 1995 [13].

From 287 deaths that occurred in 2005 among 24000 HIV positive patients followed at multiple centers in France, $48(16.7 \%)$ can be attributed to end-stage liver disease [14]. Of these, hepatitis virus coinfection was present in $45(93.8 \%)$ patients, with $38(79.2 \%)$ patients suffering from $\mathrm{HCV}$ coinfection. Excessive alcohol consumption (>30 g/day) was reported by $23(47.9 \%)$ patients in this subsequent study [14]. Alcohol consumption was related to death in $4 \mathrm{HCV} / \mathrm{HIV}$ coinfected patients $(10.5 \%)$, while HCV coinfection led to an additional 8 deaths (21.0\%) in HIV positive patients who abused alcohol, as assessed by the patients' physicians. An additional case of lethal cirrhosis was identified independent of alcohol consumption or viral hepatitis coinfection [14]. Overall, $36(75.0 \%)$ patients died from cirrhosis, 7 (14.6\%) patients died from HCV coinfection and $5(10.4 \%)$ patients died from hepatitis B virus (HBV) coinfection. Hepatitis virus coinfection $(P<0.001)$ and consuming alcohol in excess of $30 \mathrm{~g} /$ day $(P=0.005)$ were significantly associated with death due to end-stage liver disease [14].
3.1.2. Role of Cirrhosis in Disease Progression. While both HIV positivity and excessive drinking were independently associated with cirrhosis, the proportion of patients with cirrhosis was higher in HIV positive individuals (18/60, $30.0 \%)$, compared to HIV-negative individuals (23/150, $15.3 \%)(P<0.0001)$ in another French study [15]. There were no differences in the incidence of cirrhosis between HIV positive excessive drinkers and HIV-negative excessive drinkers. This should be interpreted with care, as the low number of patients included in this study, particularly HIV positive patients, could prevent the identification of an interaction between HIV positivity and excessive drinking with respect to the development of cirrhosis [15].

Among 181 cases of liver cirrhosis in a large sample of 2168 HIV positive patients, $149(82.3 \%)$ were caused by $\mathrm{HCV}, 3$ (1.6\%) were caused by HBV, 5 (2.8\%) were caused by dual HBV/HCV coinfection, and $12(6.6 \%)$ were caused by triple $\mathrm{HBV} / \mathrm{HCV} /$ hepatitis D virus coinfection [16]. Alcohol consumption, significantly associated with a diagnosis of cirrhosis, was found to be more frequent among patients with chronic viral hepatitis compared to patients without these coinfections $(P<0.001)$. Interestingly, alcohol was not found to be the only cause of cirrhosis in any one patient [16]. Aside from high alcohol consumption, coinfection with $\mathrm{HCV}$ and/or HBV are risk factors for developing liver toxicity (OR 10.36, 95\% CI 1.38-77.56, $P=0.03$ ) [17].

\subsubsection{Alcohol-Induced Inflammation Leads to Progression of HIV and Other Comorbid Reactions. Many processes related to the consumption or breakdown of alcohol that}


contribute to alcohol-induced liver disease are mediated by small proteins known as cytokines, which are produced and secreted by liver cells and many other cells throughout the body [18]. Through a variety of actions, cytokines regulate certain biochemical processes in the cells that produce them, as well as in neighbouring cells. For example, in the case of HIV infection, they attract white blood cells to the tissue, triggering an inflammatory response. In the liver, persistent cytokine secretion resulting in chronic inflammation leads to conditions such as hepatitis, fibrosis and cirrhosis. Cytokines also regulate a process known as programmed cell death, or apoptosis, which is in part responsible for alcohol-induced loss of liver tissue [19].

Dyslipidemia, consisting of hypertriglyceridemia, low high-density lipoprotein (HDL) cholesterol, and elevated low-density lipoprotein (LDL) cholesterol, is being observed with increasing frequency among persons living with HIV. Hazardous alcohol consumption, particularly among Hispanic individuals and in individuals consuming the highest amounts of alcohol, worsens dyslipidemia [20].

Alcohol use and not being on HAART $(P<0.001)$ are independent predictors of pneumonia in HIV positive smokers [21]. The incidence of pneumonia was significantly lower in the HAART era compared to the pre-HAART era $(P<$ 0.01 ), although alcohol abuse remains an independent risk factor for developing bacteremic pneumococcal disease [22].

Cerebrovascular ischemia was associated with a history of high alcohol intake, and fewer months on HAART (OR $0.97,95 \%$ CI $0.96-0.99 ; P<0.001)$. This suggests that longterm HAART has a protective effect against cerebrovascular ischemia, yet this effect is countered by a history of alcohol abuse [23].

A history of alcohol abuse or dependence was not associated with neuropathic pain caused by HIV-associated sensory neuropathy [24].

Significant differences were found between HIV positive heavy drinkers and HIV-negative light drinkers with respect to motor and visuomotor speed, pointing to a synergistic interaction between alcohol abuse and HIV infection [25].

Impaired upper limb function was observed between clinical groups (HIV positive patients, patients with alcoholism, and patients with HIV infection and alcoholism comorbidity) and controls in terms of upper motor composite score $(P=0.008$ for HIV group, $P=0.031$ for alcoholism groups and $P=0.003$ for HIV and alcoholism comorbidity group) and slower fine finger movement $(P=0.004$ for HIV group, $P=0.033$ for alcoholism groups and $P=0.0003$ for HIV and alcoholism comorbidity group) [26]. Although not significant, HIV and alcoholism comorbidity impair upper motor limb function to a greater degree that HIV alone or alcoholism alone. There were significant differences between groups with respect to closed eye composite scores (stand heel-to-toe, walk heel-to-toe, and stand on one leg with eyes closed tasks $)(P=0.013)[26]$. These differences could not be explained by the presence of peripheral neuropathy, HAART, or AIDS-defining events [26].

Immediate episodic memory was found to be impaired in HIV positive patients suffering from alcoholism, compared to either HIV positive patients without a drinking problem, HIV-negative patients suffering from alcoholism or normal controls [27]. Interestingly, these results could not be explained by the amount of alcohol consumed over a lifetime, $\mathrm{CD}^{+}$cell counts, AIDS diagnosis, or HAART medication. HIV infection or alcoholism alone did not affect immediate episodic memory. Also, working memory and the ability to retain information over time were not impaired by HIV infection or alcoholism [27].

Alcohol abuse was not associated with a longer time before clinical stability was achieved among patients who developed bacterial community-acquired pneumonia [28].

3.1.4. Nonalcoholic Steatohepatitis and HIV Disease Progression. While alcohol abuse is generally associated with HIV disease progression, several studies did not find such an association. For example, Crum-Cianflone et al. [29] found that the most common diagnosis among HIV positive patients with liver test abnormalities was that of non-alcoholic fatty liver disease. The amount of alcohol consumed per week and alcohol abuse were not predictors of liver test abnormalities. The low number of patients suffering from viral hepatitis coinfection was not high enough to uncover any effect of these comorbidities. While ART use overall did not predict liver test abnormalities, the use of protease inhibitors did $(P=0.04)$ [29]. A separate study found that alcohol consumption was not associated with HCV-related serious adverse reactions in a cohort of 1175 HIV-infected patients (1048 (89.2\%) were HCV coinfected) [30].

3.1.5. Injecting Drug Users and HIV. Compared to healthy noninjecting drug users (IDU), HIV patients who were not alcohol abusers (control population), HIV IDU only, HIV alcohol abusers, and IDU alone were each significantly associated with a lower level of $\mathrm{CD}^{+}$lymphocyte recovery $(P<0.04)$ [31]. However, no such association was found with respect to alcohol abuse alone. Compared to patients who did not abuse either alcohol or injectable drugs, no significant differences in terms of virological response (i.e., undetectable viral load) were found for either of the three study groups [31]. Unfortunately, the effects of alcohol consumption on HAART adherence are not analyzed in this study [31].

\subsection{The Role of Alcohol Consumption on the Immune System} and the HIV Viral Load. Table 2 presents some recent data on the role played by alcohol on $\mathrm{CD} 4^{+}$cell counts and the plasma viral load.

Alcohol abuse after contacting HIV seems to accelerate disease progression through a direct effect on $\mathrm{CD} 4^{+}$cells. Of note is the detrimental role played by alcohol consumption on $\mathrm{CD}^{+}$cell counts, particularly among individuals not on ART [32-36]. Heavy alcohol consumption is associated with a four times lower chance of achieving undetectable viral load and a two times higher chance of having low $\mathrm{CD}^{+}$ cell counts, compared to moderate alcohol consumption or abstinence [33]. Alcohol is an immunosuppressant acting directly through T-cell apoptosis, mitochondrial damage, and inhibition of T-cell responses, natural killer cell activity 
TABLe 2: The Role of Alcohol on the Immune System and the HIV Viral Load.

\begin{tabular}{|c|c|c|c|c|}
\hline Ref. & $\begin{array}{l}\text { Study } \\
\text { settings }\end{array}$ & Population characteristics & Alcohol use patterns & Main findings \\
\hline$[33]$ & USA & $\begin{array}{l}220 \text { HIV-1-infected IDUs receiving } \\
\text { HAART }\end{array}$ & $\begin{array}{l}\text { Heavy alcohol consumption (daily or 3-4 } \\
\text { times per/week) reported in } 139(63.2 \%) \\
\text { patients. } \\
\text { Men (OR } 2.6,95 \% \text { CI } 1.13-5.99 \\
P=0.013) \text { and participants between } 35 \\
\text { and } 45 \text { years of age more likely to be } \\
\text { heavy alcohol users }(P=0.006)\end{array}$ & $\begin{array}{l}\text { Heavy alcohol consumption associated } \\
\text { with } 4 \text { times lower chance of achieving } \\
\text { undetectable viral load and } 2 \text { times higher } \\
\text { chance of having a CD } 4^{+} \text {cell count of } \\
<500 \text { cells/ } \mu \mathrm{L} \text {, compared to moderate } \\
\text { alcohol consumption or abstinence }\end{array}$ \\
\hline$[34]$ & USA & 595 HIV positive patients & $245(41.2 \%)$ subjects consumed alcohol & $\begin{array}{l}\text { Heavy alcohol consumption associated } \\
\text { with lower CD } 4^{+} \text {cell counts only among } \\
\text { subjects not on ART }(P=0.03)\end{array}$ \\
\hline$[35]$ & USA & $231 \mathrm{HIV}$ positive drug users & $\begin{array}{l}126(54.5 \%) \text { participants consumed } \\
\text { alcohol There were } 53(22.9 \%) \text { frequent } \\
\text { alcohol users ( } \geq 2 \text { alcoholic drinks daily). } \\
\text { No differences in alcohol consumption } \\
\text { between patients on ART and patients } \\
\text { not on ART }\end{array}$ & $\begin{array}{l}\text { Frequent alcohol use ( } \geq 2 \text { drinks/day) } \\
\text { associated with } \mathrm{CD} 4^{+} \text {cell counts } \leq 200 \\
\text { cells/ } \mu \mathrm{L}(\mathrm{OR} 2.907,95 \% \text { CI } 1.233-6.855 \\
P=0.015) . \\
\text { Frequent alcohol intake associated with } \\
\text { higher viral load over time }(P=0.038)\end{array}$ \\
\hline$[36]$ & USA & $391 \mathrm{HIV}$ positive patients & $\begin{array}{l}154(39.4 \%) \text { report past week alcohol } \\
\text { consumption with mean number of } 4 \\
\text { drinks } \\
62(15.8 \%) \text { consumed }>5 \text { drinks/week }\end{array}$ & $\begin{array}{l}\text { Consuming }>5 \text { drinks/week predictor for } \\
\text { unsuppressed viral load }(\geq 400 \text { copies } / \mathrm{mL}) \\
(\text { OR } 4.2,95 \% \text { CI } 1.1-18.5, P=0.046)\end{array}$ \\
\hline$[38]$ & USA & $\begin{array}{l}2056 \text { HIV-infected women and } 569 \\
\text { HIV-uninfected women }\end{array}$ & $\begin{array}{l}33.6 \% \text { of HIV positive women consumed } \\
\geq 8 \text { drinks/week } 51.8 \% \text { of HIV positive } \\
\text { women consumed } 1-7 \text { drinks/week }\end{array}$ & $\begin{array}{l}\text { Consuming } \geq 8 \text { drinks/week related to } \\
\text { higher risk of death (OR 3.39, 95\% CI } \\
1.54-7.44, P<0.002)\end{array}$ \\
\hline$[39]$ & USA & $2702 \mathrm{HIV}$ positive patients & $\begin{array}{l}\text { Individuals were categorized as } \\
\text { nondrinkers (no alcohol consumption), } \\
\text { hazardous drinkers (consume } \geq 5 \\
\text { standard drinks on drinking days), and } \\
\text { nonhazardous drinkers (consume }<5 \\
\text { standard drinks on drinking days) }\end{array}$ & $\begin{array}{l}\text { Nonhazardous alcohol consumption } \\
\text { decreased survival by }>1 \text { year if frequency } \\
\text { of consumption was } \geq 1 \text { /week, and by } 3.3 \\
\text { years with daily consumption (from } 21.7 \\
\text { years to } 18.4 \text { years). } \\
\text { Hazardous alcohol consumption decreased } \\
\text { overall survival by }>3 \text { years if frequency of } \\
\text { consumption was } \geq 1 \text { /week, and by } 6.4 \\
\text { years with daily consumption (from } 16.1 \\
\text { years to } 9.7 \text { years) }\end{array}$ \\
\hline
\end{tabular}

and macrophage phagocytic activity. Alcohol consumption may increase susceptibility to opportunistic infections and accelerate disease progression among HIV positive individuals. Additionally, alcohol leads to impaired viral load response and reduced $\mathrm{CD}^{+}$cell reconstitution [35]. Frequent alcohol use is significantly associated with low $\mathrm{CD} 4^{+}$cell counts and higher viral loads over time [35].

In patients not on ART, heavy alcohol consumption was associated with lower $\mathrm{CD} 4^{+}$cell counts compared to patients with a history of abstinence. At-risk drinkers ( 4 drinks/week for women and 5 drinks/week for men) were less likely to have a current HAART prescription $(P<0.05)$ and were less likely to have suppressed viremia if they had a current HAART prescription $(P<0.05)$, compared to nondrinkers [36]. Consuming more than 5 drinks/week is a predictor for not being on HAART and for having an unsuppressed viral load [36]. Moreover, the risk of opportunistic infections increases as $\mathrm{CD}^{+}$cell counts decline.

The type of alcohol being consumed is important with regards to outcome in HIV positive patients currently taking HAART [37]. In subjects consuming only beer or wine, increases in thymus size and in $\mathrm{CD}^{+}$cell counts were observed following HAART initiation. In contrast, consumption of only liquor was associated with decreases in both thymus size and in $\mathrm{CD}^{+}$cell counts, particularly evident in women. Míguez-Burbano et al. [37] conclude that liquor consumption is associated with thymus deterioration and poor virologic and immunologic control in HIV positive patients taking ART.

Moderate alcohol use ( $<1$ drink per day for the past 6 months) did not significantly increase the rate in $\mathrm{CD}^{+}$ cell count decline to $\leq 200$ cells $/ \mu \mathrm{L}$, compared to abstainers. Frequent alcohol use ( $>2$ drinks/day) resulted in a risk of $\mathrm{CD} 4^{+}$cell counts decline that was almost three times higher than that for moderate alcohol use. $\mathrm{CD}^{+}$cell counts decline was faster in frequent alcohol users who were not on ART than in those who were on ART $[34,35]$. CD4 ${ }^{+}$cell counts decline was faster in frequent alcohol users who combined alcohol with crack cocaine. Viral load was found to be $0.259 \log 10$ units higher in frequent alcohol users than in moderate alcohol users and abstainers. This relationship was found to be significant in patients who were receiving ART. 
Alcohol use had no impact on HIV viral loads in patients not receiving ART. One possible explanation for these findings in that heavy alcohol use is deleterious in patients on ART because it might decrease patient adherence to ART, rather than alcohol having a direct effect on viral load [34, 35]. A drop in $\mathrm{CD}^{+}$cell counts is mediated by the direct toxic effect of alcohol on these lymphocytes, which appears to be independent of the viral load. At the same time, Samet et al. [34] argue that the beneficial effect of ART on $\mathrm{CD}^{+}$cell counts may account for a lower toxicity seen when alcohol is abused in the presence of ART.

Consuming $\geq 8$ alcoholic drinks/week was related to a higher risk of death [38]. In fact, Braithwaite et al. [39] found that alcohol consumption of any kind decreases survival in HIV positive patients.

\subsection{The Role of Alcohol Consumption on Medication Adher-} ence. Drug and/or alcohol abuse and suboptimal ART adherence are predictors of virological failure [40]. Table 3 presents studies in which alcohol consumption modulates medication adherence.

Following the introduction of HAART in 1996, individuals living with HIV taking this form of medication have benefited from improvements in immunological and virological parameters, as well as an improved quality of live and longevity [41]. However, adherence to HAART in excess of $95 \%$ is often regarded as optimal in order to benefit from this treatment [41].

3.3.1. Alcohol Consumption and Nonadherence to ART. Numerous studies from around the world document the detrimental effect of alcohol on HAART adherence, from the United States [36, 42-55], to Europe [56-61], Australia [62], Africa [63-69], South America [70, 71], and Asia [72, 73]. Alcohol consumption is associated with the first nonstructured treatment interruption, early (within the first year) versus late treatment interruption, and interruption of longer duration ( $\geq 6$ months) $[53,66]$.

In addition to nonadherence, at-risk drinkers were less likely to have a current HAART prescription. As a result, at-risk drinking was a predictor of not being on HAART $[36,51]$. In fact, all levels of drinking were associated with higher odds of not using HAART compared to alcohol abstinence [54], such that dose-dependent worsening of adherence was found with increasing alcohol consumption $[49,54,60]$. The highest degree of nonadherence was found in cases where alcohol use was classified as problem drinking (defined as meeting NIAAA criteria for at-risk drinking or diagnostic criteria for an alcohol use disorder) (OR 0.474, 95\% CI 0.408-0.550), while it was lower in studies examining any or global alcohol use (OR 0.604, 95\% CI 0.531-0.687) [41]. In the combined analysis of 40 studies reviewed in a meta-analysis, alcohol drinkers were approximately 50-60\% as likely to be classified as adherent (OR 0.548, 95\% CI 0.490-0.612) compared with abstainers (or those who drank relatively less) [41].

Concurrent crack cocaine use is associated with even lower adherence (OR 3.61, 95\% CI 1.56-8.35, P < 0.01) [51], as is a lifetime history of being an IDU (OR 2.17, 95\% CI $1.16-4.05, P=0.015)$ [70].

Nonadherence is often associated with unsuppressed viremia. For example, Shacham et al. [36] found that consuming more than 5 drinks/week is a predictor for having an unsuppressed viral load.

The reasons behind the association between alcohol consumption and nonadherence are varied. For example, due to the belief that alcohol should not be mixed with their medication, people living with HIV/AIDS may interrupt their medication when they are drinking [52] or delay HIV treatment while trying to cope with alcohol dependence [64]. Forgetfulness does seem to play an important role, as substance use by the caregiver was associated with higher odds of ART nonadherence among children in their care [42, 65]. Alcohol also appears to affect adherence to ART through conscious decisions to skip medication while drinking and not through drunken forgetfulness [45]. Based on their research, Sankar et al. [45] found that light drinkers are the most likely subgroup to miss medication.

3.3.2. Other Factors Linked to Nonadherence. Drinking patterns were found to differ across gender and ethnic groups. For example, hazardous drinking was more predominant among African-American $(P<0.01)$ and mixed race $(P<$ 0.04) patients, compared to white patients, and African American patients were less likely to report $100 \%$ adherence (OR $0.35,95 \%$ CI $0.17-0.71, P<0.01$ ) [55]. Afrodescent was marginally associated with poor adherence in a Brazilian study as well (OR 1.55, 95\% CI 0.97-2.47, $P=0.068$ ) [70]. The detrimental effects of alcohol on medication adherence seem to affect women to a greater degree than men $[44,50]$.

Several other factors are also related to nonadherence. Each additional year of life was associated with further decrease in adherence (OR 0.96, 95\% CI 0.92-1.00, $P<$ 0.04 ), while a higher level of medication-specific social support (e.g., companionship or assistance) diminished the negative effects of alcohol consumption on ART adherence (OR 1.06, 95\% CI 1.01-1.12, $P=0.01$ ) [55].

Significance of alcohol consumption diminishes once stress is factored in, suggesting that life stress may be one of the main causes for alcohol and drug consumption in HIV positive individuals, and alcohol consumption may in turn lead to nonadherence [47].

An interesting observation reported in a South African study is that many participants refused to disclose their HIV status to their family out of fear that their family would consume alcohol as result of such news, highlighting the wide-spread alcohol consumption in some communities [63].

Based on findings from these studies, it is recommended that HIV treatment programs address at-risk drinking as well [51]. The clinical evaluation of a person living with HIV should also determine the prevalence of alcohol use and/or the presence of alcohol use disorders. Moreover, an assessment of concomitant drug and alcohol use, as well as comorbidities, is needed in both men and women.

There have also been reports of no association between alcohol consumption and delayed HAART initiation [74], 
TABle 3: Alcohol Consumption and Nonadherence to ART.

\begin{tabular}{|c|c|c|c|}
\hline Ref. & $\begin{array}{c}\text { Study } \\
\text { settings }\end{array}$ & Population characteristics & Alcohol use patterns \\
\hline & & & Found Nonadherence \\
\hline$[36]$ & USA & $391 \mathrm{HIV}$ positive patients & $\begin{array}{l}154(39.4 \%) \text { report past week alcohol } \\
\text { consumption, for a mean number of } 4 \\
\text { drinks }\end{array}$ \\
\hline$[40]$ & USA & 1074 HIV positive patients & $\begin{array}{l}315(29.4 \%) \text { patients presented with } \\
\text { current or past history of drugs and/or } \\
\text { alcohol abuse }\end{array}$ \\
\hline$[42]$ & USA & $43 \mathrm{HIV}$ positive children & Alcohol abused by caregiver \\
\hline$[43]$ & USA & $\begin{array}{l}197 \text { HIV-infected } \\
\text { individuals with history of } \\
\text { alcohol problems who were } \\
\text { receiving HAART }\end{array}$ & $79(40.1 \%)$ use alcohol \\
\hline$[44]$ & USA & 1944 HIV positive patients & $\begin{array}{l}55 \% \text { of } 640 \text { men and } 28 \% \text { of } 1304 \text { women } \\
\text { consumed low levels of alcohol } \\
15 \% \text { of men and } 8 \% \text { of women } \\
\text { consumed high levels of alcohol } \\
7 \% \text { of men and } 4 \% \text { of women engaged in } \\
\text { binge drinking }\end{array}$ \\
\hline
\end{tabular}

[45] USA $\quad \begin{aligned} & 82 \mathrm{HIV} \text { positive } \\ & \text { African-American patients }\end{aligned}$

$3573(60.7 \%)$ respondents report alcohol use in past 12 months $630(17.6 \%)$ alcohol users were nonadherent

Main findings

At-risk drinkers (4 drinks/week for women and 5 drinks/week for men) are less likely to have current HAART prescription $(P<0.05)$.

At-risk drinking a predictor for not being on $\operatorname{HAART}(P=0.025)$

Current or past history of drugs and/or alcohol abuse (OR 2.10, 95\% CI 1.32-3.35, $P=0.002)$ and suboptimal adherence (OR $2.84,95 \%$ CI $1.77-4.55, P<0.001)$ predictors for virological failure

Substance use by the caregiver associated with having higher viral loads in children patients $(P=0.007)$

HIV positive drinkers less adherent to HAART than HIV positive alcohol abstainers $(P<0.05)$

Binge drinking (OR 1.75, 95\% CI 1.17-2.64, $P \leq 0.05)$, moderate-to-heavy alcohol consumption (OR 1.47, 95\% CI $1.08-1.99, P \leq 0.05)$ and low alcohol consumption (OR 1.28, 95\% CI 1.05-1.54, $P \leq 0.05)$ associated with nonadherence for women only

Alcohol can affect ART adherence through conscious decisions to skip medication while drinking and not through drunken forgetfulness

Alcohol use in past 12 months associated with nonadherence (OR 1.3, 95\% CI $1.1-1.5, P<0.05)$

Monthly alcohol consumption associated with missed medication in the past 2 weeks (OR 1.08, CI 1.02-1.15, $P<0.01)$ and over the past weekend (OR 1.09, CI 1.03-1.15, $P<0.01)$

$47(44.8 \%)$ patients missed a medication dose in the past 2 weeks, and 23 (21.9\%) missed medication during the previous weekend

275 HIV positive patients

[48] USA with alcohol use disorders $154(56.0 \%)$ patients were nonadherent

without alcohol

Mean monthly alcohol consumption was $4.64 \pm 8.00$ drinks/person

An average of 84.9 standard drinks over the thirty days prior to the baseline interview
Alcohol consumption $(P=0.001)$ and number of drinks $(P=0.002)$ related to nonadherence

Light drinking ( $<3$ drinks/week) (OR 1.51, CI 1.30-1.76, $P<0.01)$, moderate drinking (3-13 drinks/week) (OR 2.46, CI 1.96-3.09, $P<0.01)$, and heavy drinking (OR 4.37, CI 2.99-6.40, $P<0.01$ ) associated with self-reported ART nonadherence

Alcohol dependence is a specific and significant predictor of ART nonadherence in women only $(P<0.05)$ 
Table 3: Continued.

\begin{tabular}{|c|c|c|c|c|}
\hline Ref. & $\begin{array}{l}\text { Study } \\
\text { settings }\end{array}$ & Population characteristics & Alcohol use patterns & Main findings \\
\hline$[51]$ & USA & $643 \mathrm{HIV}$ positive IDUs & & $\begin{array}{l}\text { Fewer at-risk drinkers that nondrinkers } \\
\text { reported receiving ART (OR 1.19, 95\% CI } \\
0.59-2.42 \text { ) }\end{array}$ \\
\hline$[52]$ & USA & $145 \mathrm{HIV}$ positive patients & $\begin{array}{l}60(41.4 \%) \text { participants were current } \\
\text { drinkers } \\
11 \text { participants ( } 18 \% \text { of drinkers) were } \\
\text { problem drinkers (AUDIT score } \geq 8 \text { ) }\end{array}$ & $\begin{array}{l}1 \text { in } 4 \text { drinkers report stopping medication } \\
\text { while consuming alcohol } \\
\text { Alcohol use predicted treatment } \\
\text { nonadherence }(P<0.05)\end{array}$ \\
\hline$[53]$ & USA & 335 HIV positive IDUs & & $\begin{array}{l}\text { Heavy alcohol use associated with first } \\
\text { nonstructured treatment interruption (OR } \\
1.58,95 \% \text { CI } 0.92-2.70 \text { ), early (within the } \\
\text { first year) versus late treatment } \\
\text { interruption (OR } 1.55,95 \% \text { CI } 0.51-4.73 \text { ), } \\
\text { and interruption of longer duration }(\geq 6 \\
\text { months) (OR } 3.21,95 \% \text { CI } 0.83-12.5)\end{array}$ \\
\hline$[54]$ & USA & $\begin{array}{l}1354 \text { HIV positive women } \\
\text { for whom HAART was } \\
\text { indicated }\end{array}$ & & $\begin{array}{l}\text { Light drinking (OR } 1.39,95 \% \text { CI } \\
1.03-1.89, P \leq 0.05) \text {, moderate drinking } \\
\text { (OR } 1.72,95 \% \text { CI } 1.10-2.70, P \leq 0.05) \\
\text { and heavy drinking (OR } 2.29,95 \% \text { CI } \\
0.96-5.47 \text { ) associated with nonadherence, } \\
\text { compared to nondrinking }\end{array}$ \\
\hline$[55]$ & USA & $224 \mathrm{HIV}$ positive patients & $\begin{array}{l}\text { Baseline prevalence of past year } \\
\text { hazardous drinking was } 27 \% \text { (AUDIT } \\
\text { score } \geq 8 \text { ) }\end{array}$ & $\begin{array}{l}\text { Hazardous drinking associated with } \\
\text { nonadherence }\end{array}$ \\
\hline$[56]$ & France & $445 \mathrm{HIV}$ positive patients & $\begin{array}{l}329(73.9 \%) \text { patients consumed } \leq 1 \text { unit } \\
\text { of alcohol/day at baseline } \\
116(26.1 \%) \text { patients consumed }>1 \text { unit } \\
\text { of alcohol/day at baseline }\end{array}$ & $\begin{array}{l}\text { Baseline alcohol consumption associated } \\
\text { with nonsignificant nonadherence after } 4 \\
\text { months }(P=0.09)\end{array}$ \\
\hline$[57]$ & France & $\begin{array}{l}276 \text { HIV positive IDUs } \\
\text { receiving HAART }\end{array}$ & $\begin{array}{l}\text { Approximately } 84 \% \text { of patients report } \\
\text { alcohol consumption during the past } 6 \\
\text { months }\end{array}$ & $\begin{array}{l}\text { Monthly alcohol consumption during past } \\
6 \text { months associated with ART } \\
\text { nonadherence (OR } 1.15 \text {, CI } 1.08-1.23 \text {, } \\
P<0.001)\end{array}$ \\
\hline$[58]$ & France & 1010 HIV positive patients & $\begin{array}{l}59(5.8 \%) \text { patients report daily alcohol } \\
\text { consumption }\end{array}$ & $\begin{array}{l}\text { Nonadherence more common among } \\
\text { subjects who consume alcohol daily (OR } \\
0.39 \text {, CI } 0.20-0.58, P<0.001)\end{array}$ \\
\hline$[59]$ & France & $\begin{array}{l}2340 \text { HIV positive patients } \\
\text { receiving HAART. } \\
\text { Harmful alcohol } \\
\text { consumption was frequent }\end{array}$ & $\begin{array}{l}12 \% \text { of patients had symptoms of } \\
\text { potential alcohol abuse/dependence } \\
\text { during the previous } 12 \text { months (CAGE } \\
\text { questionnaire score of } \geq 2 \text { ) } \\
27 \% \text { of patients suffered from hazardous } \\
\text { drinking or alcohol use disorders } \\
\text { (AUDIT-C questionnaire score of }>4 \text { for } \\
\text { women and }>5 \text { for men) } \\
9 \% \text { of patients reported regular binge } \\
\text { drinking ( } \geq 6 \text { alcohol units drunk } \\
\text { consecutively at least twice a month) }\end{array}$ & $\begin{array}{l}\text { Harmful alcohol consumption associated } \\
\text { with nonadherence to HAART }(P<0.001) \\
\text { for regular binge drinking and symptoms } \\
\text { of alcohol abuse or dependence }\end{array}$ \\
\hline$[60]$ & Switzerland & 6709 HIV positive patients & & $\begin{array}{l}\text { Increasing alcohol intake associated with } \\
\text { deteriorating adherence to ART (OR } 1.25 \text {, } \\
95 \% \text { CI } 1.10-1.43)\end{array}$ \\
\hline$[61]$ & Sweden & $946 \mathrm{HIV}$ positive patients & $\begin{array}{l}15.5 \% \text { of patients report alcohol and drug } \\
\text { problems }\end{array}$ & $\begin{array}{l}\text { Adherent patients more likely not to have } \\
\text { problems with alcohol (OR 1.8, 95\% CI } 9 \\
1.18-3.01, P=0.008 \text { ) }\end{array}$ \\
\hline$[62]$ & Australia & $\begin{array}{l}1106 \text { HIV-infected patients } \\
867(78.4 \%) \text { report taking } \\
\text { cART, } 339 \\
(39.1 \%) \text { of which report } \\
\text { difficulty adhering to } \\
\text { medication }\end{array}$ & & $\begin{array}{l}\text { Alcohol use associated with self-reported } \\
\text { nonadherence (OR 1.47, 95\% CI } \\
1.03-2.09, P<0.05)\end{array}$ \\
\hline
\end{tabular}


TABle 3: Continued.

\begin{tabular}{|c|c|c|c|c|}
\hline Ref. & $\begin{array}{c}\text { Study } \\
\text { settings }\end{array}$ & Population characteristics & Alcohol use patterns & Main findings \\
\hline$[63]$ & $\begin{array}{l}\text { South } \\
\text { Africa }\end{array}$ & $\begin{array}{l}12 \text { HIV positive patients } \\
\text { receiving HAART }\end{array}$ & & $\begin{array}{l}\text { Alcohol abuse identified as barrier to } \\
\text { adherence }\end{array}$ \\
\hline$[64]$ & $\begin{array}{l}\text { South } \\
\text { Africa }\end{array}$ & $\begin{array}{l}8 \text { male HIV positive } \\
\text { patients }\end{array}$ & & $\begin{array}{l}\text { Patients delay HIV treatment while coping } \\
\text { with alcohol dependence }\end{array}$ \\
\hline$[65]$ & $\begin{array}{l}\text { South } \\
\text { Africa }\end{array}$ & $56 \mathrm{HIV}$ positive children & & $\begin{array}{l}\text { Alcohol use by caregiver associated with } \\
\text { poorer ART adherence in children patients } \\
(P<0.01)\end{array}$ \\
\hline$[66]$ & Cameroon & 533 HIV positive patients & $\begin{array}{l}60(11.3 \%) \text { patients reported binge } \\
\text { drinking }\end{array}$ & $\begin{array}{l}\text { Binge drinking associated with } \\
\text { interruption of ART }\end{array}$ \\
\hline$[67]$ & Ethiopia & $422 \mathrm{HIV}$ positive patients & $\begin{array}{l}31(7.3 \%) \text { subjects report alcohol } \\
\text { consumption, } 6 \text { of which did so on a } \\
\text { regular basis }\end{array}$ & $\begin{array}{l}\text { Alcohol drinking associated with } \\
\text { nonadherence (OR } 0.210, \text { CI } 0.071-0.617 \text {, } \\
P=0.003 \text { ) }\end{array}$ \\
\hline$[68]$ & Botswana & $\begin{array}{l}300 \text { adult HIV positive } \\
\text { patients }\end{array}$ & & $\begin{array}{l}\text { Alcohol use predicted poor ART adherence } \\
(P<0.02)\end{array}$ \\
\hline$[69]$ & $\begin{array}{l}\text { Benin, Côte } \\
\text { d'Ivoire, } \\
\text { and Mali }\end{array}$ & $2920 \mathrm{HIV}$ positive patients & & $\begin{array}{l}\text { Current drinking (OR } 1.4,95 \% \text { CI } \\
1.1-2.0) \text {, especially hazardous drinking } \\
\text { (OR } 4.7,95 \% \text { CI } 2.6-8.6 \text { ), associated with } \\
\text { nonadherence }\end{array}$ \\
\hline$[70]$ & Brazil & $306 \mathrm{HIV}$ positive patients & $\begin{array}{l}37.6 \% \text { of sample consumed alcohol in } \\
\text { month prior to baseline interview }\end{array}$ & $\begin{array}{l}\text { ART nonadherence associated with alcohol } \\
\text { use in month before baseline interview } \\
\text { (OR 1.61, 95\% CI 1.08-2.39, P=0.018) }\end{array}$ \\
\hline$[71]$ & Brazil & 295 HIV positive patients & $\begin{array}{l}109(37.3 \%) \text { subjects consumed alcohol } \\
\text { in month prior to baseline interview }\end{array}$ & $\begin{array}{l}\text { Nonadherence to ART associated with } \\
\text { alcohol use }(P<0.001)\end{array}$ \\
\hline$[72]$ & Thailand & 205 HIV positive patients & $\begin{array}{l}13(6.3 \%) \text { subjects report current alcohol } \\
\text { use }\end{array}$ & $\begin{array}{l}\text { Current alcohol use sole predictor of } \\
\text { nonadherence to HAART (OR 1.67, CI } \\
1.05-2.48, P<0.001 \text { ) }\end{array}$ \\
\hline$[73]$ & India & $\begin{array}{l}198 \text { HIV-infected patients } \\
\text { receiving HAART }\end{array}$ & & $\begin{array}{l}\text { Alcohol use associated with nonadherence } \\
\text { (OR 5.68, 95\% CI 2.10-15.32, } P=0.001 \text { ) }\end{array}$ \\
\hline \multicolumn{5}{|c|}{ Did Not Find Nonadherence } \\
\hline$[74]$ & USA & 1030 HIV-infected women & & $\begin{array}{l}\text { No delay in ART initiation between heavy } \\
\text { drinkers and nondrinkers }\end{array}$ \\
\hline$[75]$ & USA & $\begin{array}{l}300 \text { HIV positive men who } \\
\text { have sex with men }\end{array}$ & $\begin{array}{l}43 \% \text { of sample report alcohol } \\
\text { consumption in first } 2 \text { weeks } \\
\text { post-baseline }\end{array}$ & $\begin{array}{l}\text { No association found between alcohol use } \\
\text { and nonadherence }\end{array}$ \\
\hline$[76]$ & UK & 394 HIV positive patients & & $\begin{array}{l}\text { Excessive alcohol consumption borderline } \\
\text { significantly lower in patients receiving } \\
\text { HAART }(P<0.08)\end{array}$ \\
\hline$[77]$ & Uganda & $\begin{array}{l}2311 \text { HIV positive patients } \\
928(40.2 \%) \text { presented late } \\
\text { for treatment }\end{array}$ & $\begin{array}{l}123(5.3 \%) \text { used moderate levels of } \\
\text { alcohol and } 360(15.5 \%) \text { used high levels } \\
\text { of alcohol }\end{array}$ & $\begin{array}{l}\text { Alcohol consumption in past year } \\
\text { (assessed using AUDIT-C) negatively } \\
\text { associated with late presentation for } \\
\text { treatment (OR } 0.65,95 \% \text { CI } 0.44-0.96 \\
P=0.03 \text { for moderate use and OR } 0.79 \\
95 \% \text { CI } 0.61-1.00, P=0.05 \text { for heavy use) }\end{array}$ \\
\hline
\end{tabular}

HAART administration [29], and nonadherence [75], and even lower alcohol consumption among individuals receiving HAART [76] and earlier presentation for HAART initiation among patients consuming alcohol [77]. However, while important, such reports are relatively rare, and there is an overall considerable and consistent association between alcohol consumption and medication nonadherence [41].
3.3.3. ART Adherence and the Development of Class-Specific Medication Resistance. The association between ART adherence and the development of class-specific ART resistance represents a clinical problem. During multidrug therapy, differential drug exposure increases the likelihood of developing resistance. In addition, ART with higher potency and higher genetic barriers to resistance decrease the incidence 
of resistance for companion ART at all adherence levels. Drug resistance mutations proliferate under conditions of nonsuppressive ART, which is usually the result of inadequate drug exposure [78]. As poor adherence is the major determinant of inadequate drug exposure, ART adherence is critically linked to the development of medication resistance. In low-income countries such as South Africa where alcohol consumption is very high, nonadherence is more often producing resistance mutations, therefore leading to inadequate suppression of the HIV virus. The present review concords with the systematic review of Shuper et al. [79], bringing evidence that alcohol affects the immune system, consequently contributing to a deteriorating course of HIV disease. In addition, alcohol misuse impacts on medication adherence.

\section{Conclusions}

The primary goal of ART is to increase disease-free survival through suppression of viral replication and improvement in immunological function. The optimal time to initiate treatment is influenced by these known benefits and the risk of drug toxicity, potential emergence of viral drug resistance, and the need for lifetime therapy. The complexities of adherence-resistance relationships are related to characteristics of the virus, the medication, misuse of alcohol, and their interactions. Nevertheless, the effectiveness of ART can be limited by lack of access to therapy. Additionally, a set of acquired behaviour, such as alcohol misuse and poor adherence and/or intolerance, can lead to ART resistance. Therefore, especially in low-income populations, the education of individuals who live with HIV and alcohol abuse is relevant.

Knowledge of class-specific adherence-resistance relationships may help clinicians and patients tailor therapy to match individual patterns of adherence in order to minimize the development of resistance and treatment failure. In addition, in low-income settings, this information may guide the selection of optimal drug combinations and regimen sequences to improve the durability of ART. Moreover, alcohol use and alcohol dependence are widespread in the general population. Many people suffering from alcohol use disorders also suffer from other psychiatric disorders including drug abuse disorders. Importantly, persons living with HIV should be assessed not only for their immunologic and virologic statuses, but also for comorbidities.

This is particularly important but rarely assessed or/and reported in the literature. Modeling or condition simulation may introduce these interactions in the context of the corresponding topic leading to possible interventions.

An important objective of our study is to bring awareness of these complex interactions in the medical and education fields. Awareness should lead to cooperation between patients living with HIV, their caregivers, and researchers looking into the mechanism of relationship between the virus, disease progression, alcohol, and its comorbidities. Multiple substances of misuse, such as combined alcohol and cocaine, might be associated with behaviour and metabolic consequences not measured or not considered in these analyses. These drug-induced biological phenomena may promote disease progression and $\mathrm{CD} 4^{+}$cell loss, as well as poor adherence with prescribed medication and/or inadequate micronutrient and macronutrient intake. Because the patterns of substance abuse observed in these HIV positive cohorts might not be common or typical of other HIV populations, these findings can be generalized only to other infected populations with similar patterns of substance abuse. Further studies targeting HIV heavy alcohol users, that control for other confounding behavioural and metabolic variables, need to be conducted to confirm and extend the knowledge in this area. Moreover, a network of direct discussion is needed between people living with HIV/AIDS, medical personnel treating HIV and/or addictions, epidemiology researchers, as well as policy makers and treatment planners.

\section{Acknowledgments}

The authors acknowledge the US President's Emergency Fund for AIDS Relief (PEPFAR) through the US Centers of Disease Control and Prevention (CDC) (PO S-SF750-06-M0781), and the South African Medical Research Council for funding some of the activities that informed this paper. Its contents, however, are solely the responsibility of the authors and do not necessarily represent the official views of the CDC, PEPFAR, or other organizations referred to above.

\section{References}

[1] A. Pithey and C. Parry, "Descriptive systematic review of subSaharan African studies on the association between alcohol use and HIV infection," SAHARA-J, vol. 6, no. 4, pp. 155-169, 2009.

[2] J. Rehm and C. D. Parry, "Alcohol consumption and infectious diseases in South Africa," The Lancet, vol. 374, no. 9707, p. 2053, 2009.

[3] M. G. Neuman, M. Monteiro, and J. Rehm, "Drug interactions between psychoactive substances and antiretroviral therapy in individuals infected with human immunodeficiency and hepatitis viruses," Substance Use and Misuse, vol. 41, no. 1012, pp. 1395-1463, 2006.

[4] M. Núñez, "Hepatotoxicity of antiretrovirals: incidence, mechanisms and management," Journal of Hepatology, vol. 44, no. 1, pp. S132-S139, 2006.

[5] S. Barve, R. Kapoor, A. Moghe et al., "Focus on the liver: alcohol use, highly active antiretroviral therapy, and liver disease in HIV infected patients," Alcohol Research and Health, vol. 33, no. 3, pp. 229-236, 2010.

[6] J. Rehm, A. V. Samokhvalov, M. G. Neuman et al., "The association between alcohol use, alcohol use disorders and tuberculosis (TB). A systematic review," BMC Public Health, vol. 9, article 450, 2009.

[7] D. Quintero and D. M. Guidot, "Focus on the lung," Alcohol Research and Health, vol. 33, no. 3, pp. 219-228, 2010.

[8] M. S. Freiberg and K. L. Kraemer, "Focus on the heart: alcohol consumption, HIV infection, and cardiovascular disease," Alcohol Research and Health, vol. 33, no. 3, pp. 237-246, 2010.

[9] M. J. Rosenbloom, E. V. Sullivan, and A. Pfefferbaum, "Focus on the brain: HIV infection and alcoholism comorbidity 
effects on brain structure and function," Alcohol Research and Health, vol. 33, no. 3, pp. 247-257, 2010.

[10] C. S. Lieber, "Alcohol and the liver: 1994 update," Gastroenterology, vol. 106, no. 4, pp. 1085-1105, 1994.

[11] A. A. Chaudhry, M. S. Sulkowski, G. Chander, and R. D. Moore, "Hazardous drinking is associated with an elevated aspartate aminotransferase to platelet ratio index in an urban HIV-infected clinical cohort," HIV Medicine, vol. 10, no. 3, pp. 133-142, 2009.

[12] V. L. Vecchi, M. Soresi, C. Colomba et al., "Transient elastography: a non-invasive tool for assessing liver fibrosis in HIV/HCV patients," World Journal of Gastroenterology, vol. 16, no. 41, pp. 5225-5232, 2010.

[13] E. Rosenthal, G. Pialoux, N. Bernard et al., "Liver-related mortality in human-immunodeficiency-virusinfected patients between 1995 and 2003 in the French GERMIVIC joint study group network (MORTAVIC 2003 study)," Journal of Viral Hepatitis, vol. 14, no. 3, pp. 183-188, 2007.

[14] E. Rosenthal, D. Salmon-Céron, C. Lewden et al., "Liver-related deaths in HIV-infected patients between 1995 and 2005 in the French GERMIVIC Joint Study Group Network (Mortavic 2005 Study in collaboration with the Mortalité 2005 survey, ANRS EN19)," HIV Medicine, vol. 10, no. 5, pp. 282 289, 2009.

[15] S. Pol, B. Lamorthe, N. T. Thi et al., "Retrospective analysis of the impact of HIV infection and alcohol use on chronic hepatitis C in a large cohort of drug users," Journal of Hepatology, vol. 28, no. 6, pp. 945-950, 1998 .

[16] C. Castellares, P. Barreiro, L. Martín-Carbonero et al., "Liver cirrhosis in HIV-infected patients: prevalence, aetiology and clinical outcome," Journal of Viral Hepatitis, vol. 15, no. 3, pp. 165-172, 2008.

[17] R. Lana, M. Núñez, J. L. Mendoza, and V. Soriano, "Rate and risk factors of liver toxicity in patients receiving antiretroviral therapy," Medicina Clinica, vol. 117, no. 16, pp. 607-610, 2001.

[18] M. G. Neuman, "Cytokines - central factors in alcoholic liver disease," Alcohol Research and Health, vol. 27, no. 4, pp. 307316, 2003.

[19] M. G. Neuman, "Apoptosis in diseases of the liver," Critical Reviews in Clinical Laboratory Sciences, vol. 38, no. 2, pp. 109166, 2001.

[20] M. J. Míguez-Burbano, J. E. Lewis, and R. Malow, "Alcohol and race/ethnicity elicit different changes in lipid profiles in HIV-infected individuals receiving highly active antiretroviral therapy," Journal of the Association of Nurses in AIDS Care, vol. 20, no. 3, pp. 176-183, 2009.

[21] D. M. Murdoch, S. Napravnik, J. J. Eron Jr., and A. van Rie, "Smoking and predictors of pneumonia among HIVinfected patients receiving care in the HAART era," The Open Respiratory Medicine Journal, vol. 2, pp. 22-28, 2008.

[22] I. Grau, R. Pallares, F. Tubau et al., "Epidemiologic changes in bacteremic pneumococcal disease in patients with human immunodeficiency virus in the era of highly active antiretroviral therapy," Archives of Internal Medicine, vol. 165, no. 13, pp. 1533-1540, 2005.

[23] I. Corral, C. Quereda, A. Moreno et al., "Cerebrovascular ischemic events in HIV-1-infected patients receiving highly active antiretroviral therapy: incidence and risk factors," Cerebrovascular Diseases, vol. 27, no. 6, pp. 559-563, 2009.

[24] R. J. Ellis, D. Rosario, D. B. Clifford et al., "Continued high prevalence and adverse clinical impact of human immunodeficiency virus-associated sensory neuropathy in the era of combination antiretroviral therapy: the CHARTER study," Archives of Neurology, vol. 67, no. 5, pp. 552-558, 2010.
[25] M. K. Baum, C. Rafie, S. Lai, S. Sales, J. B. Page, and A. Campa, "Alcohol use accelerates HIV disease progression," AIDS Research and Human Retroviruses, vol. 26, no. 5, pp. 511$518,2010$.

[26] R. Fama, J. C. Eisen, M. J. Rosenbloom et al., "Upper and lower limb motor impairments in alcoholism, HIV infection, and their comorbidity," Alcoholism: Clinical \& Experimental Research, vol. 31, no. 6, pp. 1038-1044, 2007.

[27] R. Fama, M. J. Rosenbloom, B. N. Nichols, A. Pfefferbaum, and E. V. Sullivan, "Working and episodic memory in HIV infection, alcoholism, and their comorbidity: baseline and 1-year follow-up examinations," Alcoholism: Clinical \& Experimental Research, vol. 33, no. 10, pp. 1815-1824, 2009.

[28] G. Madeddu, E. M. Porqueddu, F. Cambosu et al., "Bacterial community acquired pneumonia in HIV-infected inpatients in the highly active antiretroviral therapy era," Infection, vol. 36, no. 3, pp. 231-236, 2008.

[29] N. Crum-Cianflone, G. Collins, S. Medina et al., "Prevalence and factors associated with liver test abnormalities among human immunodeficiency virus-infected persons," Clinical Gastroenterology and Hepatology, vol. 8, no. 2, pp. 183-191, 2010.

[30] M. A. Loko, D. Salmon, P. Carrieri et al., "The French national prospective cohort of patients co-infected with HIV and HCV (ANRS CO13 HEPAVIH): early findings, 2006-2010," BMC Infectious Diseases, vol. 10, article 303, 2010.

[31] T. J. Henrich, N. Lauder, M. M. Desai, and A. N. Sofair, "Association of alcohol abuse and injection drug use with immunologic and virologic responses to HAART in HIVpositive patients from urban community health clinics," Journal of Community Health, vol. 33, no. 2, pp. 69-77, 2008.

[32] S. Pol, "Improvement of the CD4 cell count after alcohol withdrawal in HIV-positive alcoholic patients," AIDS, vol. 10, no. 11, pp. 1293-1294, 1996.

[33] M. J. Miguez, G. Shor-Posner, G. Morales, A. Rodriguez, and X. Burbano, "HIV treatment in drug abusers: impact of alcohol use," Addiction Biology, vol. 8, no. 1, pp. 33-37, 2003.

[34] J. H. Samet, D. M. Cheng, H. Libman, D. P. Nunes, J. K. Alperen, and R. Saitz, "Alcohol consumption and HIV disease progression," Journal of Acquired Immune Deficiency Syndromes, vol. 46, no. 2, pp. 194-199, 2007.

[35] M. K. Baum, C. Rafie, S. Lai, S. Sales, J. B. Page, and A. Campa, "Alcohol use accelerates HIV disease progression," AIDS Research and Human Retroviruses, vol. 26, no. 5, pp. 511$518,2010$.

[36] E. Shacham, A. Agbebi, K. Stamm, and E. T. Overton, "Alcohol consumption is associated with poor health in HIV clinic patient population: a behavioral surveillance study," AIDS and Behavior, vol. 15, no. 1, pp. 209-213, 2009.

[37] M. J. Míguez-Burbano, J. E. Lewis, J. Fishman, D. Asthana, and R. M. Malow, "The influence of different types of alcoholic beverages on disrupting highly active antiretroviral treatment (HAART) outcome," Alcohol and Alcoholism, vol. 44, no. 4, pp. 366-371, 2009.

[38] N. A. Hessol, A. Kalinowski, L. Benning et al., "Mortality among participants in the Multicenter AIDS Cohort Study and the Women's Interagency HIV Study," Clinical Infectious Diseases, vol. 44, no. 2, pp. 287-294, 2007.

[39] R. S. Braithwaite, J. Conigliaro, M. S. Roberts et al., "Estimating the impact of alcohol consumption on survival for HIV+ individuals," AIDS Care, vol. 19, no. 4, pp. 459-466, 2007.

[40] G. K. Robbins, K. L. Johnson, Y. Chang et al., "Predicting virologic failure in an HIV clinic," Clinical Infectious Diseases, vol. 50, no. 5, pp. 779-786, 2010. 
[41] C. S. Hendershot, S. A. Stoner, D. W. Pantalone, and J. M. Simoni, "Alcohol use and antiretroviral adherence: review and meta-analysis," Journal of Acquired Immune Deficiency Syndromes, vol. 52, no. 2, pp. 180-202, 2009.

[42] S. Naar-King, C. Arfken, M. Frey, M. Harris, E. Secord, and D. Ellis, "Psychosocial factors and treatment adherence in paediatric HIV/AIDS," AIDS Care, vol. 18, no. 6, pp. 621-628, 2006.

[43] M. M. Finucane, J. H. Samet, and N. J. Horton, "Translational methods in biostatistics: linear mixed effect regression models of alcohol consumption and HIV disease progression over time," Epidemiologic Perspectives and Innovations, vol. 4, article 8, 2007.

[44] M. Lazo, S. J. Gange, T. E. Wilson et al., "Patterns and predictors of changes in adherence to highly active antiretroviral therapy: longitudinal study of men and women," Clinical Infectious Diseases, vol. 45, no. 10, pp. 1377-1385, 2007.

[45] A. Sankar, T. Wunderlich, S. Neufeld, and M. Luborsky, "Seropositive African Americans' beliefs about alcohol and their impact on anti-retroviral adherence," AIDS and Behavior, vol. 11, no. 2, pp. 195-203, 2007.

[46] P. S. Sullivan, M. L. Campsmith, G. V. Nakamura, E. B. Begley, J. Schulden, and A. K. Nakashima, "Patient and regimen characteristics associated with self-reported nonadherence to antiretroviral therapy," PLoS ONE, vol. 2, no. 6, Article ID e552, 2007.

[47] J. Leserman, G. Ironson, C. O'Cleirigh, J. M. Fordiani, and E. Balbin, "Stressful life events and adherence in HIV," AIDS Patient Care and STDs, vol. 22, no. 5, pp. 403-411, 2008.

[48] J. T. Parsons, E. Rosof, and B. Mustanski, "Medication adherence mediates the relationship between adherence selfefficacy and biological assessments of HIV health among those with alcohol use disorders," AIDS and Behavior, vol. 12, no. 1, pp. 95-103, 2008.

[49] M. Plankey, P. Bacchetti, C. Jin et al., "Self-perception of body fat changes and HAART adherence in the women's interagency HIV study," AIDS and Behavior, vol. 13, no. 1, pp. 53-59, 2009.

[50] A. J. Applebaum, M. A. Richardson, S. M. Brady, D. J. Brief, and T. M. Keane, "Gender and other psychosocial factors as predictors of adherence to highly active antiretroviral therapy (HAART) in adults with comorbid HIV/AIDS, psychiatric and substance-related disorder," AIDS and Behavior, vol. 13, no. 1, pp. 60-65, 2009.

[51] K. Arasteh and D. C. Des Jarlais, "HIV testing and treatment among at-risk drinking injection drug users," Journal of the International Association of Physicians in AIDS Care, vol. 8, no. 3, pp. 196-201, 2009.

[52] S. C. Kalichman, C. M. Amaral, D. White et al., "Prevalence and clinical implications of interactive toxicity beliefs regarding mixing alcohol and antiretroviral therapies among people living with HIV/AIDS," AIDS Patient Care and STDs, vol. 23, no. 6, pp. 449-454, 2009.

[53] R. Kavasery, N. Galai, J. Astemborski et al., "Nonstructured treatment interruptions among injection drug users in Baltimore, MD," Journal of Acquired Immune Deficiency Syndromes, vol. 50, no. 4, pp. 360-366, 2009.

[54] M. Lillie-Blanton, V. E. Stone, A. Snow Jones et al., "Association of race, substance abuse, and health insurance coverage with use of highly active antiretroviral therapy among HIVinfected women, 2005," American Journal of Public Health, vol. 100, no. 8, pp. 1493-1499, 2010.

[55] K. Lehavot, D. Huh, K. L. Walters, K. M. King, M. P. Andrasik, and J. M. Simoni, "Buffering effects of general and medication-specific social support on the association between substance use and HIV medication adherence," AIDS Patient Care and STDs, vol. 25, no. 3, pp. 181-189, 2011.

[56] B. Spire, S. Duran, M. Souville, C. Leport, F. Raffi, and J. P. Moatti, "Adherence to highly active antiretroviral therapies (HAART) in HIV-infected patients: from a predictive to a dynamic approach," Social Science and Medicine, vol. 54, no. 10, pp. 1481-1496, 2002.

[57] P. Roux, M. P. Carrieri, V. Villes et al., "The impact of methadone or buprenorphine treatment and ongoing injection on highly active antiretroviral therapy (HAART) adherence: evidence from the MANIF2000 cohort study," Addiction, vol. 103, no. 11, pp. 1828-1836, 2008.

[58] C. Protopopescu, F. Raffi, P. Roux et al., "Factors associated with non-adherence to long-term highly active antiretroviral therapy: a 10 year follow-up analysis with correction for the bias induced by missing data," Journal of Antimicrobial Chemotherapy, vol. 64, no. 3, pp. 599-606, 2009.

[59] L. Michel, M. P. Carrieri, L. Fugon et al., "Harmful alcohol consumption and patterns of substance use in HIVinfected patients receiving antiretrovirals (ANRS-EN12VESPA Study): relevance for clinical management and intervention," AIDS Care, vol. 22, no. 9, pp. 1136-1145, 2010.

[60] T. R. Glass, M. Battegay, M. Cavassini et al., "Longitudinal analysis of patterns and predictors of changes in self-reported adherence to antiretroviral therapy: swiss HIV cohort study," Journal of Acquired Immune Deficiency Syndromes, vol. 54, no. 2, pp. 197-203, 2010.

[61] B. Södergård, M. Halvarsson, M. P. Tully et al., "Adherence to treatment in Swedish HIV-infected patients," Journal of Clinical Pharmacy and Therapeutics, vol. 31, no. 6, pp. 605616, 2006.

[62] J. Grierson, R. L. Koelmeyer, A. Smith, and M. Pitts, "Adherence to antiretroviral therapy: factors independently associated with reported difficulty taking antiretroviral therapy in a national sample of HIV-positive Australians," HIV Medicine, vol. 12, no. 9, pp. 562-569, 2011.

[63] J. B. Nachega, A. R. Knowlton, A. Deluca et al., "Treatment supporter to improve adherence to antiretroviral therapy in HIV-infected South African adults: a qualitative study," Journal of Acquired Immune Deficiency Syndromes, vol. 43, supplement 1, pp. S127-S133, 2006.

[64] M. Fitzgerald, M. Collumbien, and V. Hosegood, "No one can ask me "Why do you take that stuff?": men's experiences of antiretroviral treatment in South Africa," AIDS Care, vol. 22, no. 3, pp. 355-360, 2010.

[65] H. B. Jaspan, A. D. Mueller, L. Myer, L.-G. Bekker, and C. Orrell, "Effect of caregivers' depression and alcohol use on child antiretroviral adherence in South Africa," AIDS Patient Care and STDs, vol. 25, no. 10, pp. 595-600, 2011.

[66] R. Manfredi and L. Calza, "HIV infection and the pancreas: risk factors and potential management guidelines," International Journal of STD \& AIDS, vol. 19, no. 2, pp. 99-105, 2008.

[67] K. A. Beyene, T. Gedif, T. Gebre-Mariam, and E. Engidawork, "Highly active antiretroviral therapy adherence and its determinants in selected hospitals from south and central Ethiopia," Pharmacoepidemiology and Drug Safety, vol. 18, no. 11, pp. 1007-1015, 2009.

[68] N. T. Do, K. Phiri, H. Bussmann, T. Gaolathe, R. G. Marlink, and C. W. Wester, "Psychosocial factors affecting medication adherence among HIV-1 infected adults receiving combination antiretroviral therapy (cART) in Botswana," AIDS Research and Human Retroviruses, vol. 26, no. 6, pp. 685691, 2010. 
[69] A. Jaquet, D. K. Ekouevi, J. Bashi et al., "Alcohol use and nonadherence to antiretroviral therapy in HIV-infected patients in West Africa," Addiction, vol. 105, no. 8, pp. 1416-1421, 2010.

[70] P. D. F. Bonolo, C. C. César, F. A. Acúrcio et al., "Non-adherence among patients initiating antiretroviral therapy: a challenge for health professionals in Brazil," AIDS, vol. 19, supplement 4, pp. S5-S13, 2005.

[71] P. De Fátima Bonolo, C. J. Machado, C. C. César, M. D. G. B. Ceccato, and M. D. C. Guimarães, "Vulnerability and non-adherence to antiretroviral therapy among HIV patients, Minas Gerais State, Brazil," Cadernos de Saude Publica, vol. 24, no. 11, pp. 2603-2613, 2008.

[72] D. Kitkungvan, A. Apisarnthanarak, P. Laowansiri, and L. M. Mundy, "Secure antiretroviral therapy delivery in a resourcelimited setting: streamlined to minimize drug resistance and expense," HIV Medicine, vol. 9, no. 8, pp. 636-641, 2008.

[73] K. K. Venkatesh, A. K. Srikrishnan, K. H. Mayer et al., "Predictors of nonadherence to highly active antiretroviral therapy among HIV-infected South Indians in clinical care: implications for developing adherence interventions in resource-limited settings," AIDS Patient Care and STDs, vol. 24, no. 12, pp. 795-803, 2010.

[74] R. C. Neblett, H. E. Hutton, B. Lau, M. E. McCaul, R. D. Moore, and G. Chander, "Alcohol consumption among HIVinfected women: impact on time to antiretroviral therapy and survival," Journal of Women's Health, vol. 20, no. 2, pp. 279286, 2011 .

[75] P. N. Halkitis, A. H. Kutnick, and S. Slater, "The social realities of adherence to protease inhibitor regimens: substance use, health care and psychological states," Journal of Health Psychology, vol. 10, no. 4, pp. 545-558, 2005.

[76] C. J. Smith, I. Levy, C. A. Sabin, E. Kaya, M. A. Johnson, and M. C. I. Lipman, "Cardiovascular disease risk factors and antiretroviral therapy in an HIV-positive UK population," HIV Medicine, vol. 5, no. 2, pp. 88-92, 2004.

[77] I. M. Kigozi, L. M. Dobkin, J. N. Martin et al., "Latedisease stage at presentation to an HIV clinic in the era of free antiretroviral therapy in Sub-Saharan Africa," Journal of Acquired Immune Deficiency Syndromes, vol. 52, no. 2, pp. 280289, 2009.

[78] E. M. Gardner, W. J. Burman, J. F. Steiner, P. L. Anderson, and D. R. Bangsberg, "Antiretroviral medication adherence and the development of class-specific antiretroviral resistance," AIDS, vol. 23, no. 9, pp. 1035-1046, 2009.

[79] P. A. Shuper, M. Neuman, F. Kanteres, D. Baliunas, N. Joharchi, and J. Rehm, "Causal considerations on alcohol and HIV/AIDS-a systematic review," Alcohol and Alcoholism, vol. 45, no. 2, pp. 159-166, 2010. 


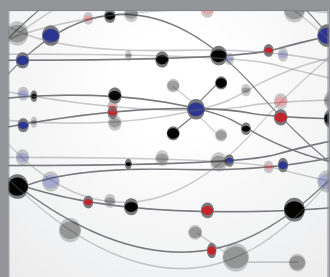

The Scientific World Journal
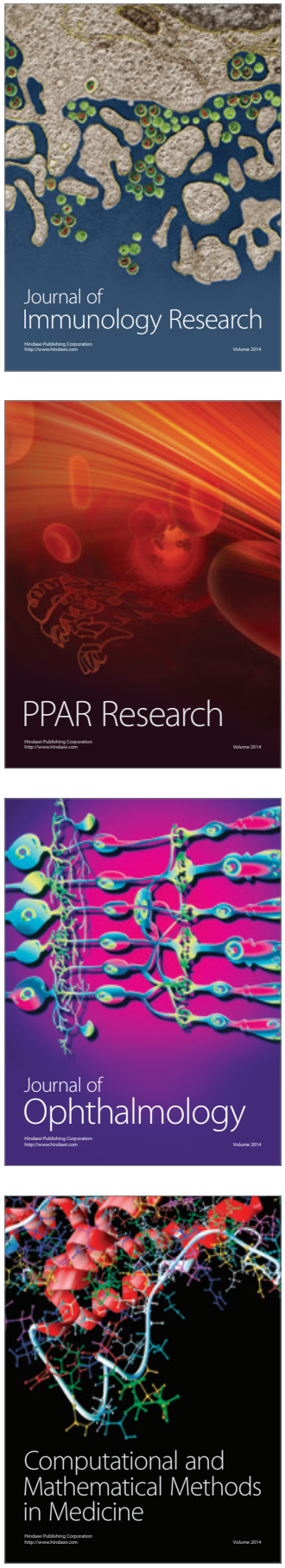

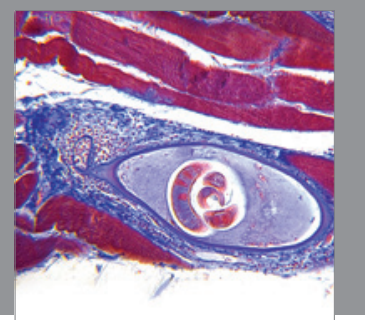

Gastroenterology

Research and Practice
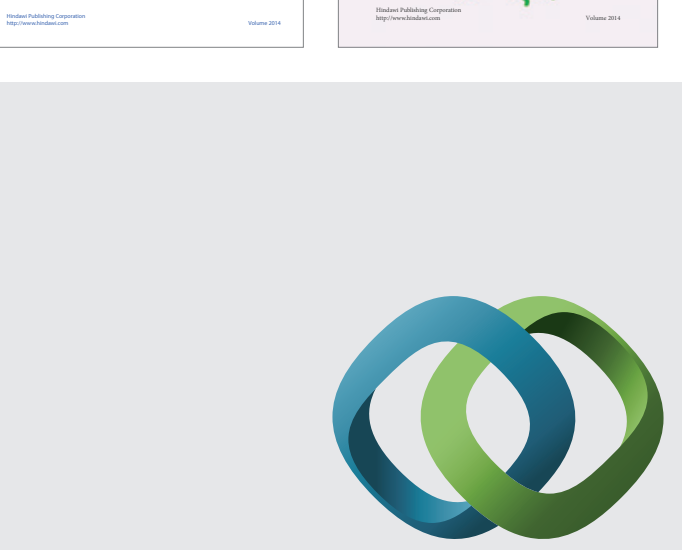

\section{Hindawi}

Submit your manuscripts at

http://www.hindawi.com
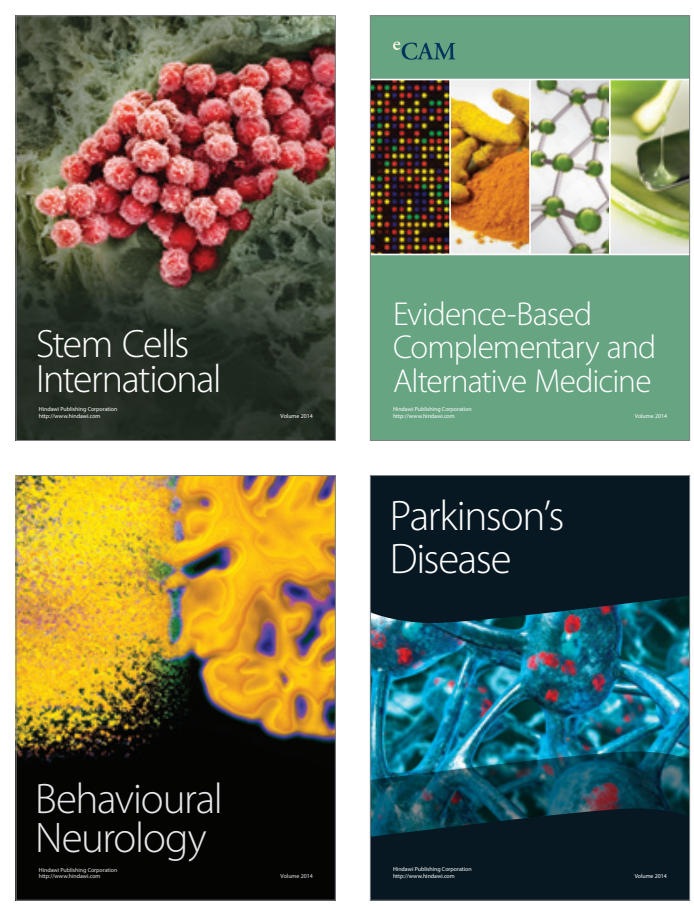

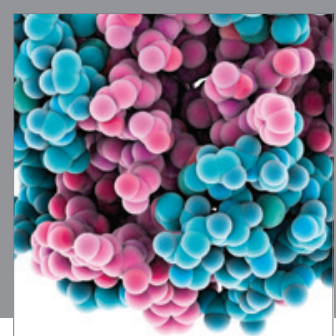

Journal of
Diabetes Research

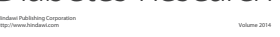

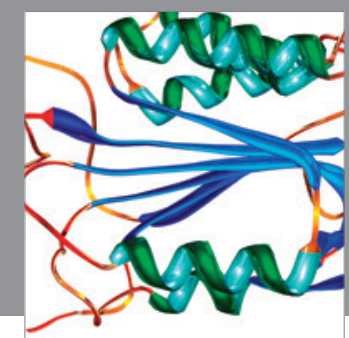

Disease Markers
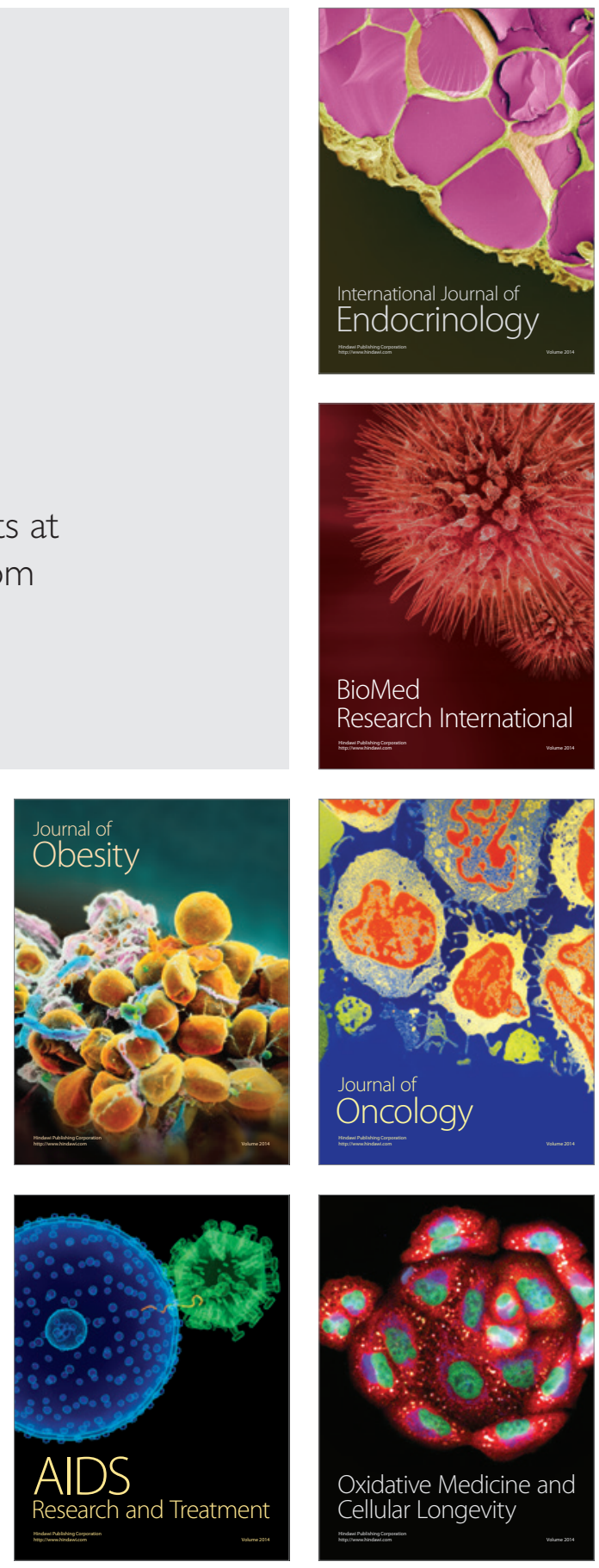